Olga Śpiewak ${ }^{1}$, Renata Stasiak-Betlejewska ${ }^{2}$

\title{
QUALITY ISSUES IN THE FIELD \\ OF INTERNATIONAL STUDENTS EXCHANGE MOBILITY IN POLAND AND CZECH REPUBLIC UNDER ERASMUS+ PROGRAMME
}

\begin{abstract}
International exchanges programs are one of the most important directions of contemporary European universities development. The quality level of the international exchange of students and academic staff determines not only the quality level of the education, but it also creates directions of the future research through the prism of international cooperation between universities and students. Papers presents research findings on the international exchange students' mobility under Erasmus+ programme between Polish and Czech universities in 2000 - 2014. The main objective of the research is to identify the most important elements of the Erasmus+ mobility results as advantages and disadvantages of the international cooperation between analyzed countries.
\end{abstract}

Key words: international students Exchange, mobility, Erasmus+, quality

\section{Erasmus program and its statistics}

The Erasmus program was established in 1987 as a student exchange program. Main idea behind it is: to develop international cooperation between universities. It is addressed primarily to universities, their students and employees. It enables students' trips abroad for part of their studies and practice, encourages the mobility of university staff, and creates numerous opportunities for universities to participate in projects with foreign partners. In some of his events it may participates other

\footnotetext{
${ }^{1}$ BSc, Master student, Student' Scientific Group Erasmus+Manager, Erasmus mobility student, Faculty of Management, Częstochowa University of Technology, Poland, e-mail: spiewakola@gmail.com

2 Ing. PhD., supervisor of Student' Scientific Group Erasmus+Manager, department coordinator of Erasmus+ programme, Faculty of Management, Częstochowa University of Technology, Poland, e-mail: renatastasiak@wp.pl
} 
institutions, organizations or companies that cooperate with universities. Participation in the Erasmus program is entitled by the universities Erasmus University Charter, awarded by the European Commission. It is a certificate that allows the university to apply for funding for specific actions established in the program. The Charter is usually given for a period of many years. Countries that participated in the Erasmus program in 2013/14:

- 28 member countries of the EU: Austria, Belgium, Bulgaria, Croatia, Cyprus, Czech Republic, Denmark, Estonia, Finland, France, Greece, Spain, Netherlands, Ireland, Luxembourg, Lithuania, Latvia, Malta, Poland, Portugal, Romania, Slovakia, Slovenia, Sweden, Hungary, Great Britain, Italy;

- 3 European Economic Area countries: Iceland, Liechtenstein, Norway;

- Turkey;

- Switzerland;

- Republic of Macedonia (in some activities).

In the academic year 2013/2014, there were 212208 students who went abroad to study on Erasmus mobility ( $70 \%$ of students on the first degree of study, $28 \%$ on Master, $1 \%$ on the PhD. studies and $1 \%$ of students in short-cycle). The average age of students who have participated in the exchange during studies is 23.4 years. In period 2013/2014, students were sent by 2407 higher education institutions. Women represented greater part of participants $(60.2 \%)$.

Since the beginning of the program, in 1987, it has considerable increase of the students' number both to practice and study at foreign universities. In the first year of the program of the students' exchange 3244 students went abroad. An academic year later, this number has tripled, a year later it has been nearly doubled. The objective of the European Commission was that by 2012, 3 million students would have benefited from Erasmus and by the year 2020 up to $6 \%$ of EU students would have participated in this mobility. In the year 2002/2003 there was already more than a million students and in 2009/2010, more than 2 
million, whereas in academic year 2012/2013 target was achieved, and more than 3 million students benefited from funding from the program. This number continues to increase from year to year. The following data is shown in Figure 1.

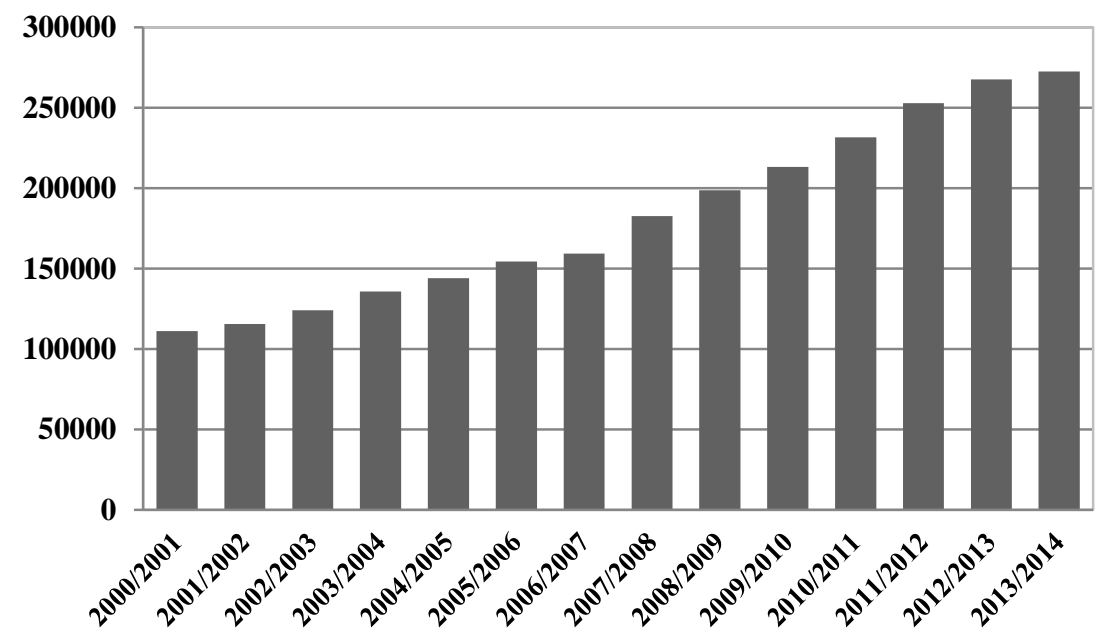

Fig. 1. The number of students mobility in European countries since academic year 2000/2001.

Source: own study based on:

http://www.erasmus.org.pl/odnosniki-

podstawowe/statystyki\#Mobilnosc_w_ramach_Erasmusa_w_Polsce_-

_dane_w_podziale_na_uczelnie;

Narodowa Agencja Programu Erasmus+, Warszawa 2015, Erasmus w Polsce w roku akademickim 2013/2014, ISBN: 978-83-64032-82-0

Among the top receiving countries, to which came the largest number of students in the year 2013/2014:
1. 37235 in Spain.
2. 36759 in France.
3. 36257 in Germany.
4. 26331 in Italy. 
5. 15610 in United Kingdom.

6. 15610 in Poland.

7. 15060 in Turkey.

8. 10638 in Netherlands.

9. 7754 in Belgium.

10. 7510 in Czech Republic.

In the year 2013/2014 almost two times more students came to Poland than to the Czech Republic. Spain, France and Germany have proven to be leaders of the classification. These countries were visited by the largest number of students numbering about 36 thousand each.

The European Union supports especially students who have the poor economic background and want to study at foreign colleges. In the academic year 2013/2014 Poland was the leader in the awarding of such grants, there were 130 of them. In the second place were Germany with the number of 68 grants, and Italy was third with the 53 grants. Czech was at one of the last places with a number of 7 grants. The chart below shows a number of financial grants in specific countries.

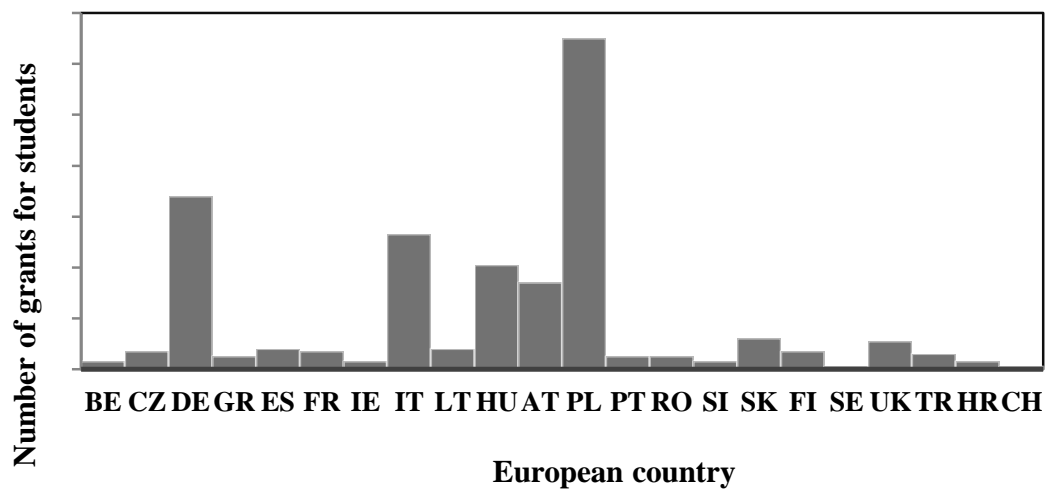

Fig. 2. The number of grants for students with special needs in 2013/2014.

Source: own study based on Erasmus - Facts, Figures \& Trends. The European Union support for student and staff exchanges and university cooperation in 2013-14 Luxembourg: Publications Office of the European Union. 
The beginning of the Erasmus program in Poland took place in 1998. From that time until the year of 2013/2014 331 colleges have acquired the Erasmus University Charter and the 238 colleges for specific actions of the Erasmus program as part of the financing agreement signed with the National Agency. In total in years, 1998/99 - 2013/14: 155092 trips of Polish students under Erasmus, 68089 arrivals of foreign students to Poland, 46400 trips of Polish staff, 20015 arrivals of foreign workers to the Poland colleges. In the academic year 2013/2014 took place on 15 517 trips of students, including 11381 trips to college. Data presented in table 1 show results from 10 foreign universities where the largest number of Polish students in the year 2013/2014 was noted.

Table 1.The number of Polish students in European countries on Erasmus+exchange mobility

\begin{tabular}{|l|l|c|}
\hline University & Country & $\begin{array}{c}\text { Number of received } \\
\text { Polish students }\end{array}$ \\
\hline Universidad de Granada & Spain & 111 \\
\hline Univerza v Ljubljani & Slovenia & 106 \\
\hline $\begin{array}{l}\text { Universidad Politecnica } \\
\text { de Valencia }\end{array}$ & Spain & 99 \\
\hline Univerzita Karlova v Praze & Czech Republic & 98 \\
\hline Universitat de Valencia & Spain & 94 \\
\hline $\begin{array}{l}\text { Universidade Tecnicac de } \\
\text { Lisboa }\end{array}$ & Portugal & 87 \\
\hline Universidade da Beira Interior & Portugal & 86 \\
\hline Via University College & Denmark & 79 \\
\hline Universita degli Studi di Bari & Italy & 78 \\
\hline Sveuclliste u Zagrebu & Croatia & 77 \\
\hline
\end{tabular}

Source: own study based on Narodowa Agencja Programu Erasmus+, Warszawa 2015, Erasmus w Polsce w roku akademickim 2013/2014, ISBN: 978-83-64032-82-0. 
In the first place is the University in Spain, in Grenade, in the year 2013/2014 there were taken in 111 Polish students. In second place with a difference of only 5 students was University in Ljubljana - the capital of Slovenia. Third place is also Spain and the fourth of Charles University in Prague. The differences between individual universities are small. At the last place among the most frequently visited universities by Poles was Svecliliste in Zagreb.

\section{Research object analysis - Poland and Czech Republic international students mobility within Erasmus+ programme}

In the year 2013/14 Poland at its disposal the amount of 47,039,000 Euros from the European Union funds. $76.05 \%$ percent of this amount, or $32,125,099$ was allocated to student mobility whereas $12.66 \%$ or $5,682,273$ of the mobility of workers. In contrast, only $9.2 \%$ or $4,130,440$ on organizations mobility. The money allowed the financial support of the mobility of students. Average monthly scholarship for the trip under the Erasmus program in 98/99 amounted to 375 Euro. This sum gradually decreased until in 03/04 it reached a threshold of 148 Euro. A year later, the average scholarship was as high as 266 Euro. Year after year, it steadily grew. The economic crisis did not prevent further increases in the amount of the grant. In 2013/14 it amounted to 410 Euro and it keeps rising. 


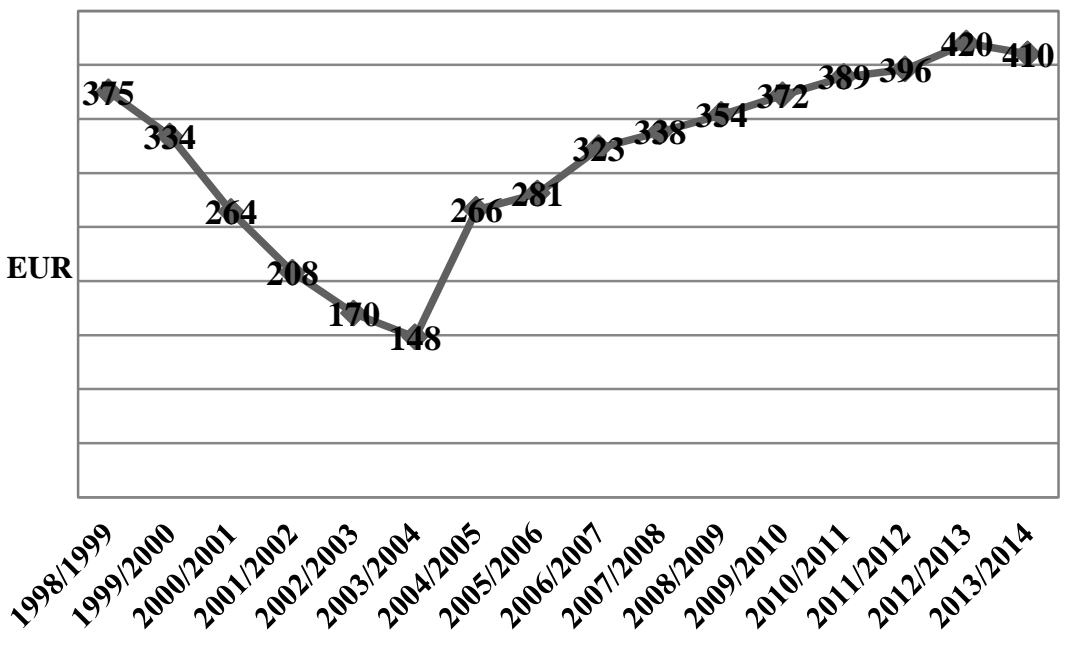

Fig. 3. The number of Erasmus scholarship 1998-2014.

Source: own study based on Erasmus - Facts, Figures \& Trends. The European Union support for student and staff exchanges and university cooperation in 2013-14 Luxembourg: Publications Office of the European Union.

\subsection{Erasmus+ mobility in Czech Republic}

Today, over 39,000 foreign students are studying in the Czech Republic. There are 24 public/2 state/44 private higher education institutions. It is an increasingly popular destination for international study and the EU statistics released in 2014 listed the Czech Republic as the 10th most popular destination for Erasmus students in Europe. There are certainly many reasons for choosing the Czech Republic as a study destination: universities with long-standing reputations, unique conception and interesting specializations, affordable tuition fees and living costs, and last but not least, a vibrant and colourful cultural life in the heart of Europe. Erasmus+ enables students to study or train in a company abroad, as well as providing higher education staff with a 
chance to train or teach abroad. The figures given below refer to "Erasmus exchanges" during the last year of the previous programme (Lifelong learning).

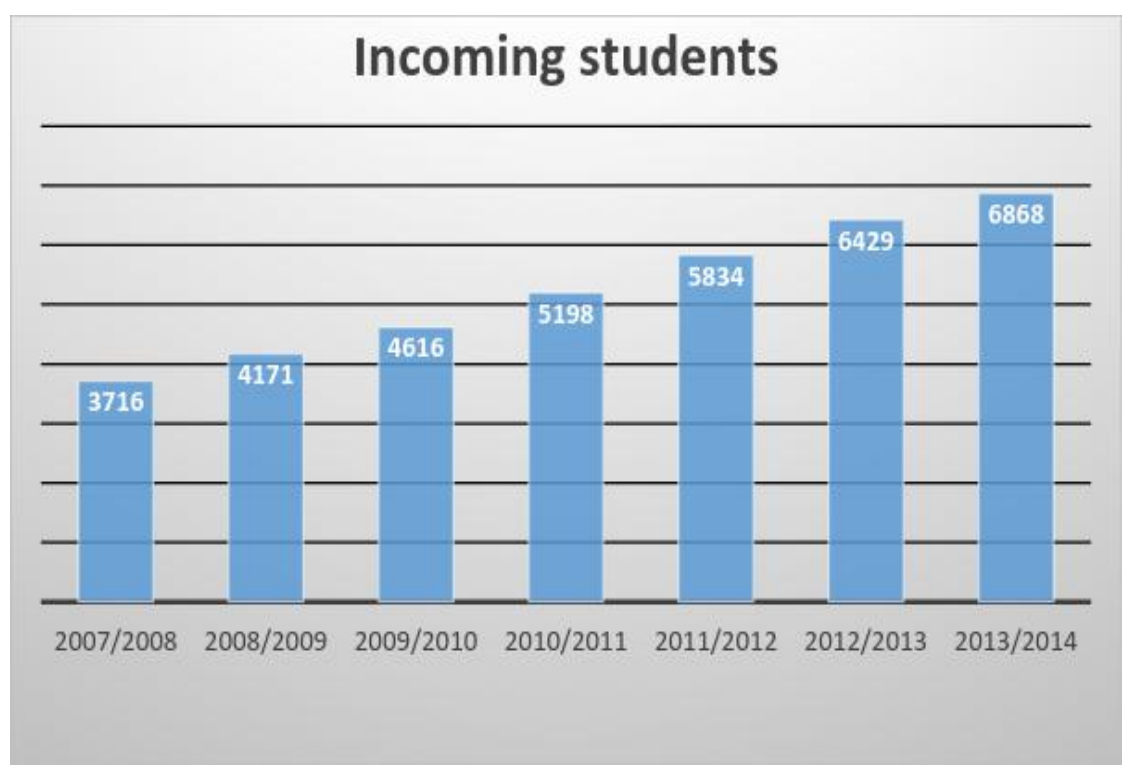

Fig. 4. The number of incoming students in Czech Republic in 2007-2014.

Source: own study based on http://ec.europa.eu/education/library/statistics/2014/czechrepublic_en.pdf

Data presented in Figure 6.4 shows increasing number of students going on Erasmus to the Czech Republic in 2007/2008. Data analysis shows the sum of interns and students in a given year. The increase within seven years has almost doubled. From the number of 3716 in $2007 / 2008$ to $2013 / 2014$, this level has risen to 6,868. Most selected universities in the Czech Republic are:

1. UNIVERZITA KARLOVA V PRAZE

2. CESKÉ VYSOKÉ UCENÍ TECHNICKÉ V PRAZE

3. MASARYKOVA UNIVERZITA 


\section{VYSOKÉ UCENÍ TECHNICKÉ V BRNE}

\section{CESKA ZEMEDELSKA UNIVERZITA V PRAZE}

Whereas most frequently dialled countries for Czech students are:

1. Germany

2. France

3. Spain

4. United Kingdom

5. Portugal

Data analysis was concluded in the form of the description of two universities from the Czech Republic that are very popular among students from among the other countries.

The first is the Czech University of Life Sciences Prague (CULS) that is one of the leading life sciences universities in Europe, and as such is a member of the Euro league for Life Sciences. In 2013/2014, CULS was a temporary home for nearly three thousand international students from 86 countries. In the academic year 2013/2014 it hosted 380 students from all around Europe in the framework of Erasmus programme. In this connection the university is looking forward to the newly inaugurated Erasmus+ programme of the EU, which will allow it to implement student/staff mobility schemes with new partners, throughout the world. As it is one of the top universities in the Czech Republic, international cooperation is top priority for the university. CULS has signed more than 180 Inter Institutional Agreements with universities throughout Europe, and 90 Memorandums of Understanding with universities around the world. Furthermore, CULS is member of several important international university networks, including the Euro league for Life Sciences (ELLS). Main information about University:

- Faculties (6),

- Departures (60),

- Number of BSc study programmes taught in English (8),

- Number of MSc study programmes taught in English (18),

- PhD study programme fields of specialization in English (23),

- International students (2 850 in 2013/2014), 
- Enrolled students (2 600).

CULS offers three different groups of courses for students. First of this is "regular courses" taught in weekly sessions (lectures and seminars). Second is courses that contain of regular (weekly sessions: lectures and seminars) + BLOCK teaching (for couple of days). To get credits students MUST attend both parts (weekly sessions AND BLOCK). BLOCK teaching is an educational method, when teacher from abroad comes to CULS for couple of days and gives an intensive teaching to our students.

Another proposition for Erasmus students is Charles University. Since 1998, Charles University has been active in the Erasmus programme (former Socrates/Erasmus and LLP/Erasmus; now Erasmus+) with a steadily growing number of student and teacher exchanges. Today Charles University has signed more than 2000 Inter-Institutional Agreements with almost 900 partner institutions. Study at Charles University can be interesting for many reasons. Charles University with its three seats Prague (14 faculties), Hradec Králové ( 2 faculties) and Pilsen ( 1 faculty) is an excellent place. Charles University provides entire degree programmes taught in English, as well as a number of individual course units taught in English, German and French. The chart below shows a line number of outgoing and incoming students to the Charles University. As you can see the trend is upward since 1999. In the first arrivals of students it was 130, seven years later already 863 and in the academic year 2013/2014 it became as big as 1402 .

Charles University is the most internationally respected university in the Czech Republic featuring a relatively high rate of international full time students, almost $15 \%$, and this number tends to grow. In both Shanghai (ARWU) and The Times Higher Education Supplement World University Ranking (THE), Charles University is the only Czech institution of higher education to rank among the top 500 universities. In the CHE multiranking, Charles University features 4 Research Areas of Excellence, which is the best result among higher education institutions from the new EU states. Its ranking makes the university one of the $1.5 \%$ 
of the world's best universities and one of the Europe's Top 100 universities. Charles University stresses international cooperation with prestigious educational and scientific establishments that occupy top positions in the international ranking in both research and education. It has entered into more than 1600 bilateral agreements within the Erasmus+ programme and almost 200 interuniversity agreements with foreign universities. Charles University participates in a dozen of joint degree programmes with prestigious partners from Europe and overseas.

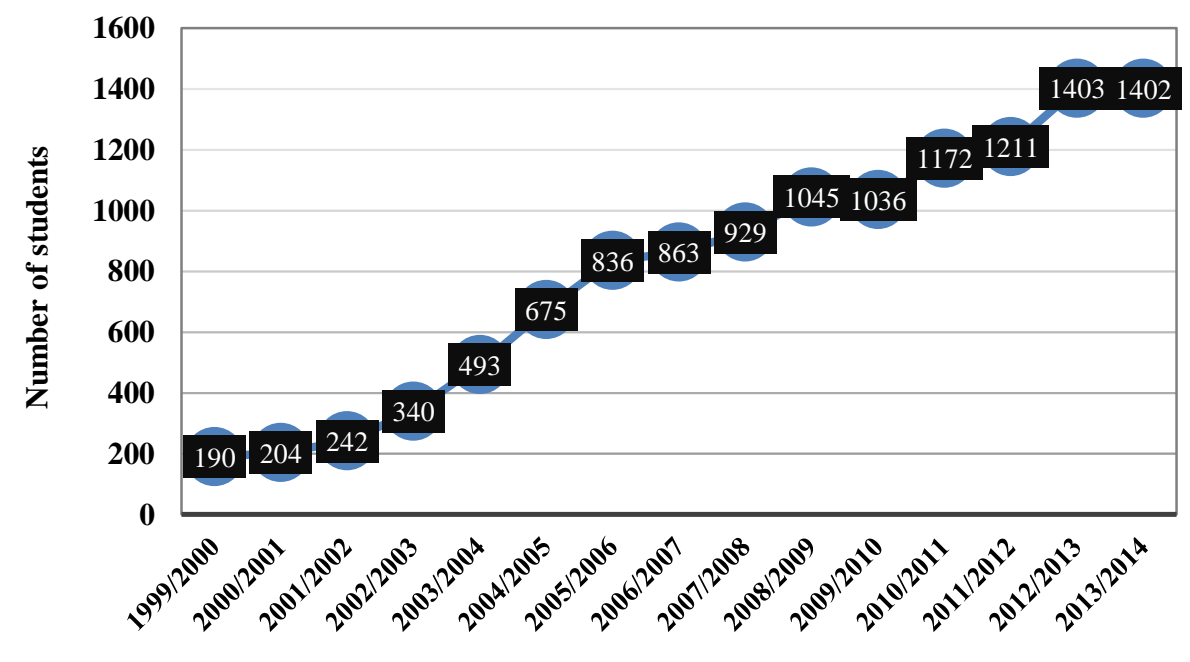

Fig. 5. The number of incoming students at Charles University in 1999 - 2014.

Source: own study based on http://www.cuni.cz/UKEN-142.html

\subsection{Erasmus+ mobility in Poland}

There were two universities in Poland whose data on Erasmus mobility were analyzed in the paper. The University of Warsaw in Poland (UW) was established in 1816 and it is the largest and finest university in Poland. The University of Warsaw offers 43 major fields and over 100 
specializations in the Humanities, Earth, Social, and Natural Sciences. Currently, the university has 19 faculties and 28 independent research and education units, employs over 3150 academic and research staff, and educates 58000 students. Over 2000 single courses and 18 whole study programs in foreign languages.

The University of Warsaw concluded agreements with over 300 academic partners from 60 countries. In recent years, the relations with Asian universities have seen the most dynamic development. The University of Warsaw actively cooperates also with European, North and South American universities. Many of the agreements concluded by the University of Warsaw refer to the exchange of students, doctoral students and employees.

In 2010 the European Commission chose UW as one of 20 European Success Stories in Fostering Internationalisation at European universities. Ranked number 1 in Erasmus mobility in Poland Foundation for The Development of the Education System - Erasmus National Agency awarded "A Mobility Friendly University".

University of Warsaw is the most popular destination for foreign students. In the academic year 2013/2014661 students studied for the Erasmus program. The biggest group of students from Spain, had as many as 137 . The second place was taken by Germany and Italy with the number 107 and 91 students. From the Czech Republic it was only 16 people. The chart below includes the number of students from different countries who have started studies at the University of Warsaw. 


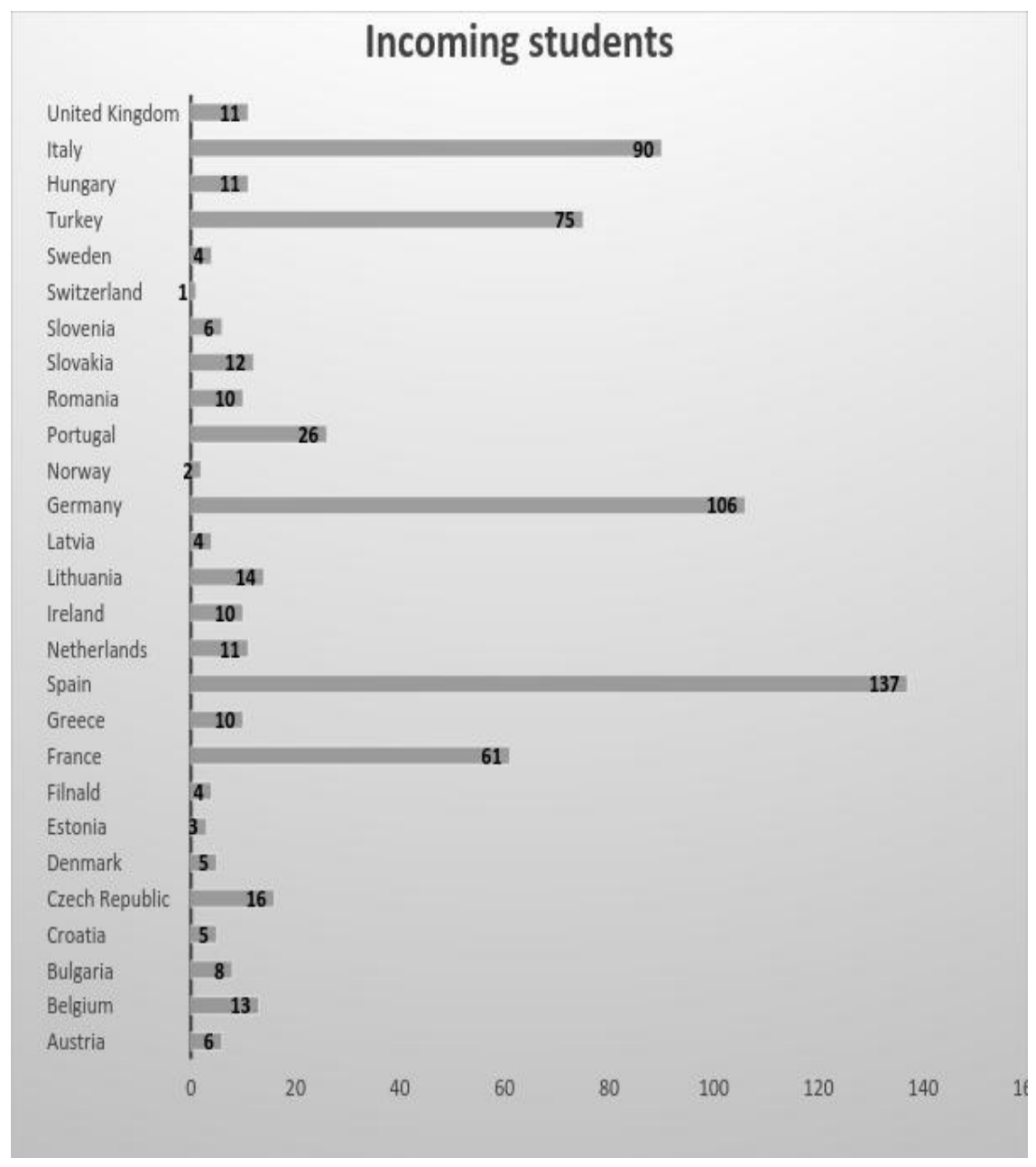

Fig. 6. The number of incoming students at University of Warsaw2013/2014. Source: own study based on http://www.erasmus.org.pl/odnosniki-podstawowe/statystyki

The firth analyzed university in regard to Erasmus students exchange programme was Częstochowa University of Technology in Poland. It is the smallest university from the presented above. Czestochowa University of Technology (CUT) is the largest state university in the 
region funded in the 40's last century. The University is involved in several research projects within the framework of Programmes, research and education initiatives. It takes an active part in the Seventh Framework Programme (e.g. in the PEOPLE MARIE CURIE campaign and ENERGY sub-programme), and in numerous COST and the NORWEGIAN FINANCIAL MECHANISM projects.

Currently in its educational offer on the first-cycle degree level (Bachelor level) there are 5 fields of study held in English (7 semesters): $\mathrm{BSc}$

- in Biotechnology for Environmental Protection,

- in Business and Technology,

- in Intelligent Energy,

- in Computer Modelling and Simulation,

- in Management and Production Engineering

On the second - cycle degree level (Masters level) there are 4 fields of study (4 or 3 semesters) MSc in:

- Management,

- Management and Production Engineering,

- Computational Intelligence and Data Mining,

- in Modelling and Simulation in Mechanics,

- in Logistics.

All lectures, classes and projects are conducted entirely in English. Częstochowa University of Technology in the academic year took 39 students from the Erasmus program. Most students came from Romania (19). In second place in terms of the amount of people was Turkey that sent 10 students. There are also 5 students who came from Spain, 2 from the Czech Republic and France, and 1 student from Slovenia and 1 from Slovakia. 


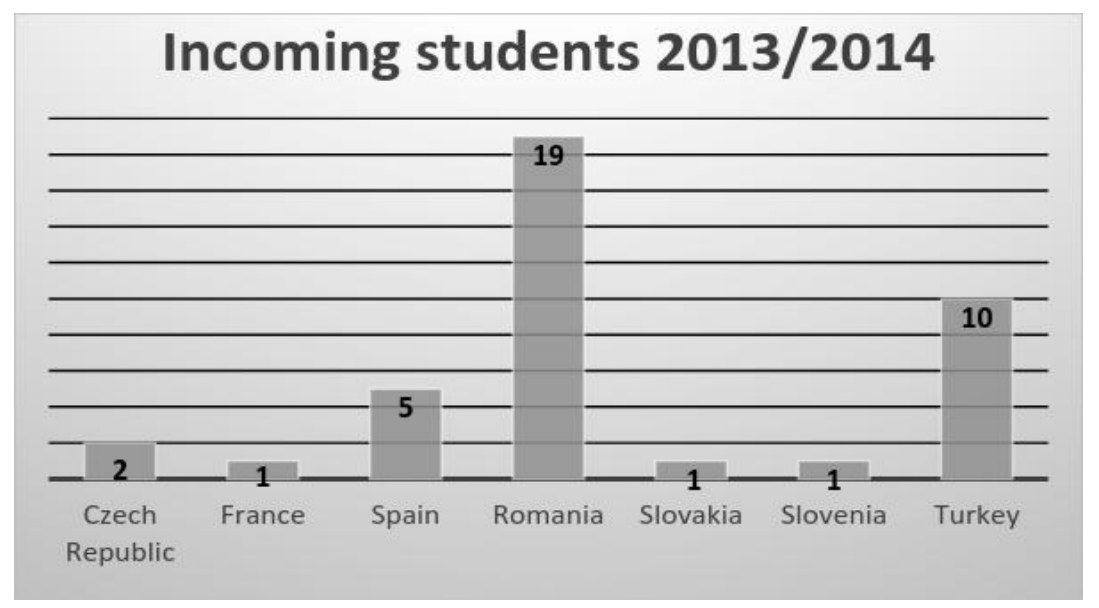

Fig. 7. The number of incoming students at Czestochowa University of Technology in the academic year 2013/2014.

Source: own study based on:

http://www.erasmus.org.pl/odnosniki-

podstawowe/statystyki\#Mobilnosc_w_ramach_Erasmusa_w_Polsce_-

_dane_w_podziale_na_uczelnie

Students of Częstochowa University of Technology outgoing within Erasmus+ Exchange mobility programme for studies and internship in 2015 have participated in Action 1 KA103 Higher Education. Total number of students/Erasmus+ mobility programme was presented in Table 6.2 and it amounted 62 in 2015 (60 students have participated in Erasmus+ study mobility and 2 students participated in Erasmus+ traineeship).

Data presented in Table 2 confirms the highest number of outgoing students at Częstochowa University of Technology was reached by Faculty of Management (32). 
Table 62. The number of outgoing students to Erasmus+ mobility programme partners of Częstochowa University of Technology in 2015

\begin{tabular}{|c|c|c|c|}
\hline $\begin{array}{l}\text { Faculties } \\
\text { at Częstochowa University of Technology }\end{array}$ & $\begin{array}{c}\text { Study } \\
\text { mobility } \\
\text { (SMS) }\end{array}$ & $\begin{array}{c}\text { Internship } \\
\text { mobility } \\
\text { (SMP) }\end{array}$ & $\begin{array}{c}\text { Total } \\
\text { number } \\
\text { of mobilities } \\
\text { (SMS+SMP) }\end{array}$ \\
\hline Faculty of Management & 30 & 2 & 32 \\
\hline $\begin{array}{l}\text { Faculty of Mechanical Engineering } \\
\text { and Computer Science }\end{array}$ & 13 & - & 13 \\
\hline Faculty of Electrical Engineering & 5 & - & 5 \\
\hline Faculty of Civil Engineering & 4 & - & 4 \\
\hline Faculty of Infrastructure and Environment & 6 & - & 6 \\
\hline $\begin{array}{l}\text { Faculty of Production Engineering } \\
\text { and Materials Technology }\end{array}$ & 2 & - & 2 \\
\hline Total & 60 & - & 62 \\
\hline
\end{tabular}

Source: own elaboration based on report of Centre of International Students, Czestochowa University of Technology.

The academic year 2014/2015 was the sixteenth year of students' mobility at Częstochowa University of Technology while the year 2015 was the second year of students exchange mobility within the Erasmus+ programme (Action 1 action KA103 - Higher Education) in accordance to a new Card Erasmus for 2014-2020 given by the European Commission. In addition, students' mobility has been covered by social scholarship received from the increased funds for mobility within Programme PO WER HE. Students have been in 2015 year in the following European countries: Hungary, Germany, Spain, Romania, Slovenia, Slovakia, the Czech Republic, Greece, Turkey, France, and Portugal. Percentage of 
outgoing students of different faculties who visited in partner institutions under Erasmus + KA 103 is presented in Figure 8.

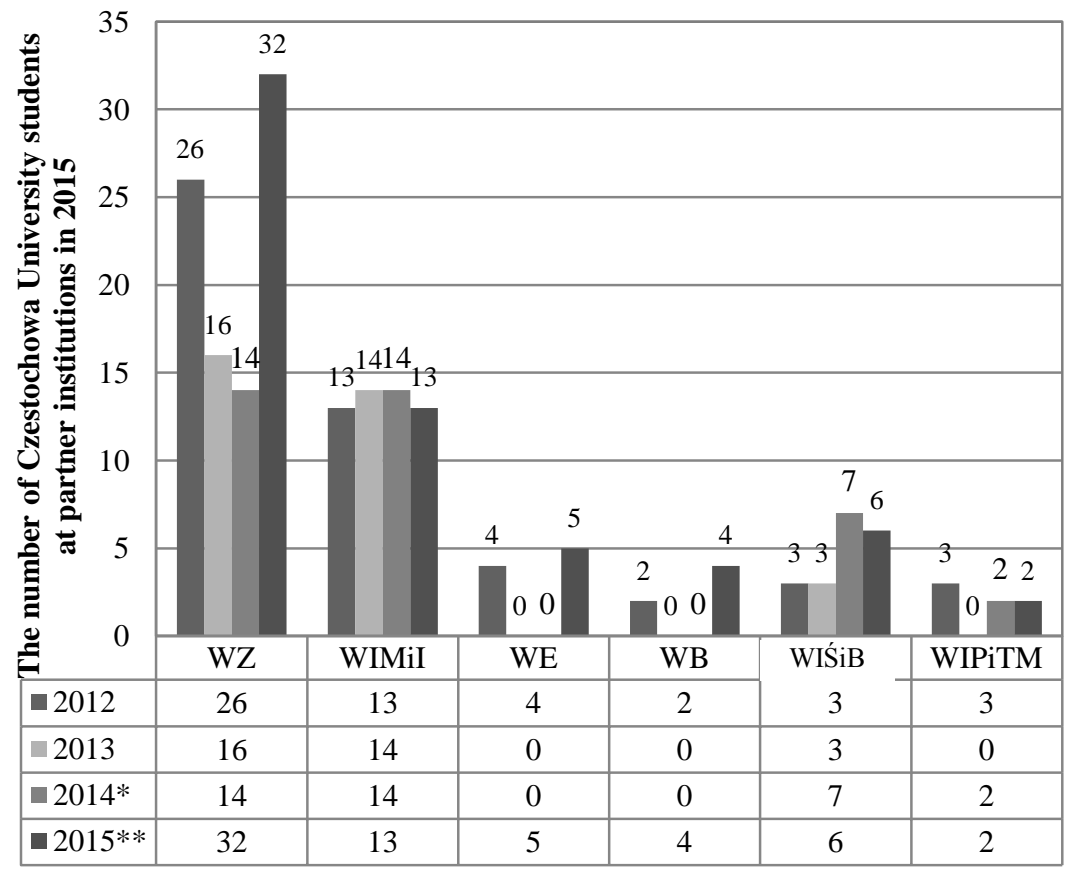

* Since 01-01-2014 (Winter semester 2013/2014, Spring semester 2013/2014, Winter semester $2014 / 2015$ to $31-12-2014$ )

** Since 01-01-2015 (Winter semester 2014/2015, Spring semester 2014/2015winter semester $2015 / 2016$ to $31-12-2015$ )

WZ - Faculty of Management

WIMiI - Faculty of Mechanical Engineering and Computer Science

WE - Faculty of Electrical Engineering

WB - Faculty of Civil Engineering

WIŚiB - Faculty of Infrastructure and Environment

WIPiTM - Faculty of Production Engineering and Materials Technology

Fig. 8. The number of outgoing students of Częstochowa University of Technology to partner institutions under Erasmus+ exchange mobility.

Source: own elaboration based on report of Centre of International Students, Czestochowa University of Technology. 
The number of foreign (incoming) students staying at the Częstochowa University of Technology in the framework of international mobility for studies and internship in 2015 under programs LLP-Erasmus and Erasmus + (Action 1 action KA103 Higher Education) was presented in Figure 9.

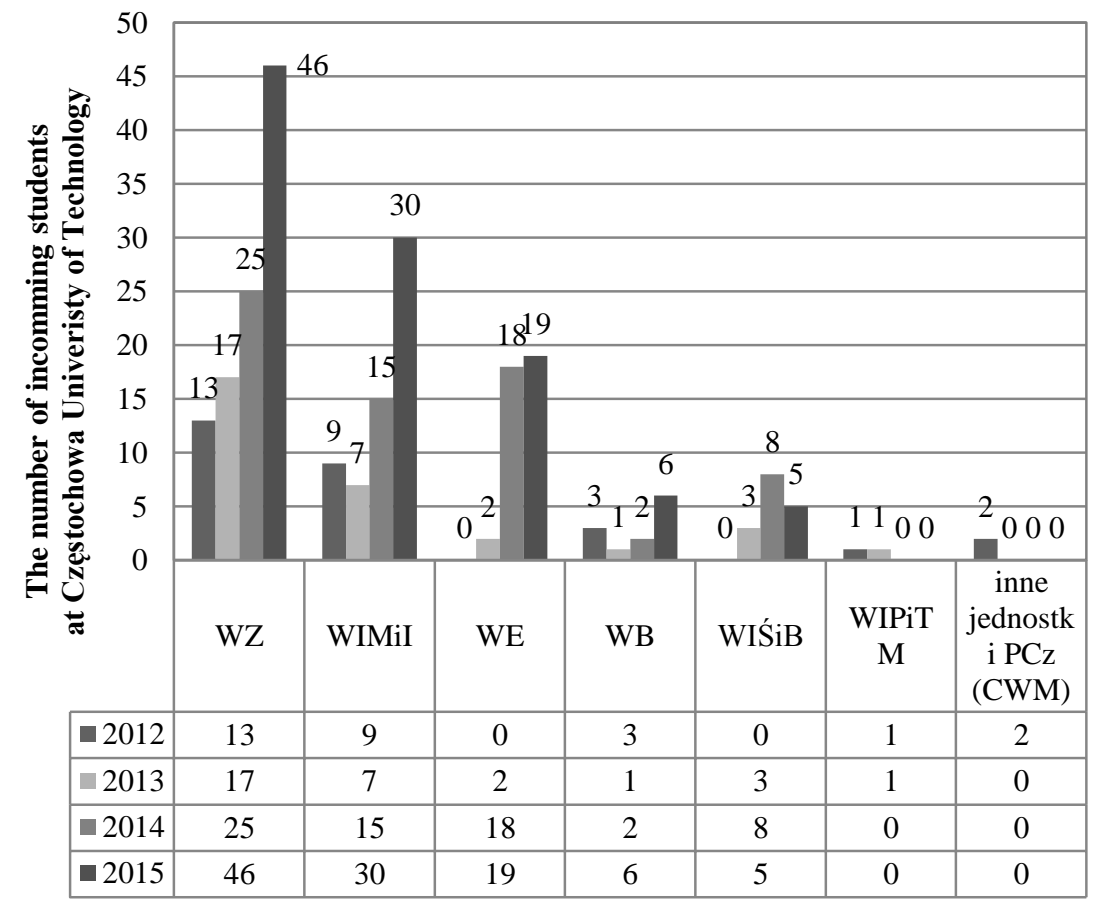

* total number of Erasmus+ mobilities for study and internship (practice)

WZ - Faculty of Management

WIMiI - Faculty of Mechanical Engineering and Computer Science

WE - Faculty of Electrical Engineering

WB - Faculty of Civil Engineering

WIŚiB - Faculty of Infrastructure and Environment

WIPiTM - Faculty of Production Engineering and Materials Technology

Fig. 9. The number of incoming students of Czestochowa University of Technology to partner institutions under Erasmus+ exchange mobility.

Source: own elaboration based on report of Centre of International Students, Czestochowa University of Technology. 
In the analyzed period, 106 incoming students have been noted at Częstochowa University of Technology, who:

study mobility (SMS):

- WZ (Faculty of Management) - 46;

- WIMiI (Faculty of Mechanical Engineering and Computer Science) - 30;

- WE (Faculty of Electrical Engineering) - 12;

- WB (Faculty of Civil Engineering) - 6;

- WIŚiB (Faculty of Infrastructure and Environment) - 5;

- WIPiTM (Faculty of Production Engineering and Materials Technology) -0 .

Practice mobility (SMP):

- WZ (Faculty of Management) - 0;

- WIMiI (Faculty of Mechanical Engineering and Computer Science) -0 ;

- WE (Faculty of Electrical Engineering) - 7;

- WB (Faculty of Civil Engineering) - 7;

- WIŚiB (Faculty of Infrastructure and Environment) - 0;

- WIPiTM (Faculty of Production Engineering and Materials Technology) -0 .

A significant increase within Erasmus+ mobility was noted in total number of mobilities (139 mobilities in 2014 in comparison to 214 in 2015). It is worth noting that the overall increase in the international mobility of the year amounted to more than $42.5 \%$, in the mobility of incoming students amounted to $156 \%$ compared to the previous year.

One of the most often mentioned reason of the choice of Czestochowa University of Technology by incoming students is location of the university and conditions of the studying including the education offer $(92 \%)$.

\section{Research findings and discussion}

The purpose of the survey was to check the preferences of choice of place of Erasmus mobility with regard to quality issues on the mobility (education offer, attractiveness of the university location and the living 
conditions). In the survey there were included questions that explain what guided the students while choosing University and the city to which they planned to go. Research survey results concerns replies of 100 students from different European countries who are at the present time on the exchange with the Erasmus program or are planning such a trip. The vast majority of them have already been on the exchange program Erasmus$89 \%$ and the rest of the people have not. The majority of respondents were Polish students (33\%), Czech students (25\%), French students $(16 \%)$, Portuguese $(9 \%)$, Spanish students $(6 \%)$, students from Belgium $(5 \%)$, students from Croatia (2\%), students from Slovenia (2\%) and 1 student from the Netherlands and 1student from Germany. Most respondents came from large towns (over 400 thousand people), which is $45 \%, 37 \%$ came from medium-sized towns - less than 400 thousand people and $18 \%$ were from towns of less than 100 thousand people. Women were the majority among respondents (63\%). Questions regarding education have shown that 74 students are located on the first stage of study and 26 students were on the master studies. None of the respondents had a higher degree of studies. Among the types of studies the results were comparable and 55\% of studied humanistic faculties and $45 \%$ of technical.

The first question concerned the "Types of classes offered by universities." Most of the people participating in the survey - 57\% chose the option "Regular classes and Consultations." So the combination of the two previous answers. Then "Classes in regular group with other students" was identified by $21 \%$ of respondents, while the "Individual classes with teacher (Consultations)" was identified by 23\% (Fig. 6.10). 


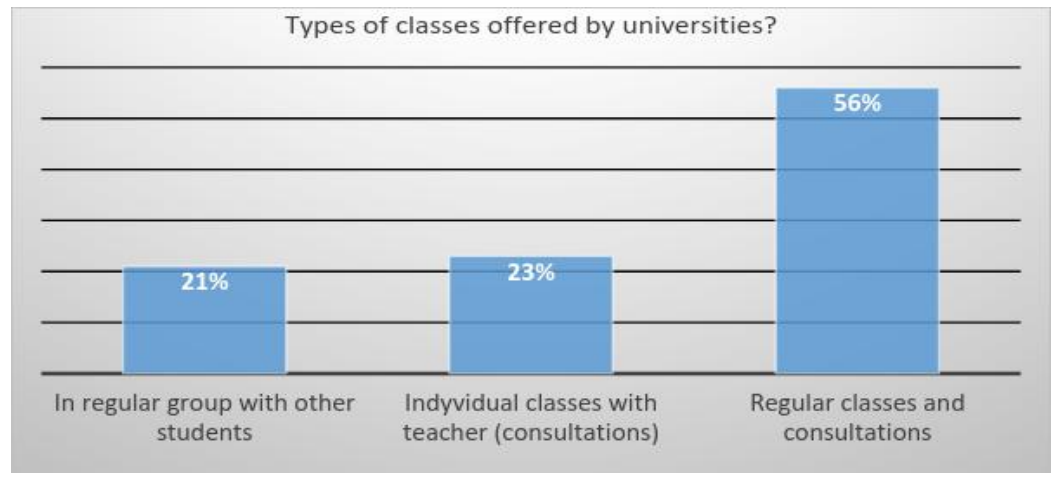

Fig. 10. Types of classes offered by universities in the opinion of respondents.

Source: own study.

The next question of the survey concerns the activities on ELearning. In this question up to 97 percent of students answered yes, only $3 \%$ said no. In this question it can be seen that working remotely is very important as the students prefer to learn their dwelling place than at the courses at universities. The question "What language are the classes taught in?" students could enter the language in which classes could be held (Fig. 11). The victory of the English language over other languages was not surprising. Students specified only two other languages: French (13\%) and Spanish (9\%). This question showed that students want to develop other known by them languages. 


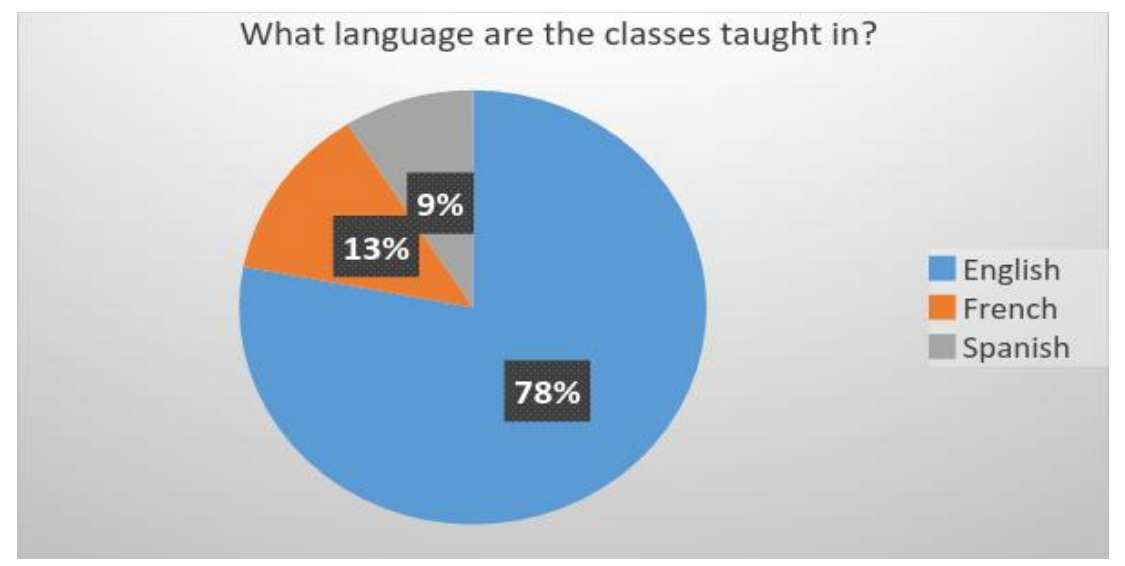

Fig. 11. What language are the classes taught in?

Source: own study.

Analysis of the respondents answers to the question "What kind of extra classes do you prefer?" shown that $65 \%$ of respondents indicated "languages". More than $30 \%$ of respondents would like to participate in sports. One person mentioned the art classes and the another one - music classes. In the next question, "Possibility of accommodation in dormitories?" majority of students (86\%) answered "Yes" that was related to the opportunity to live in a dormitory.

The question "How big city do you prefer for Erasmus mobility?" shown that students prefer the big city for the place of departure (Fig. 12). The second most frequently chosen answer was found on the following point averages city with the result "does not matter" which means that no important is the size of the city. The village of less than 100 thousand inhabitants was chosen only by $4 \%$ of respondents. 


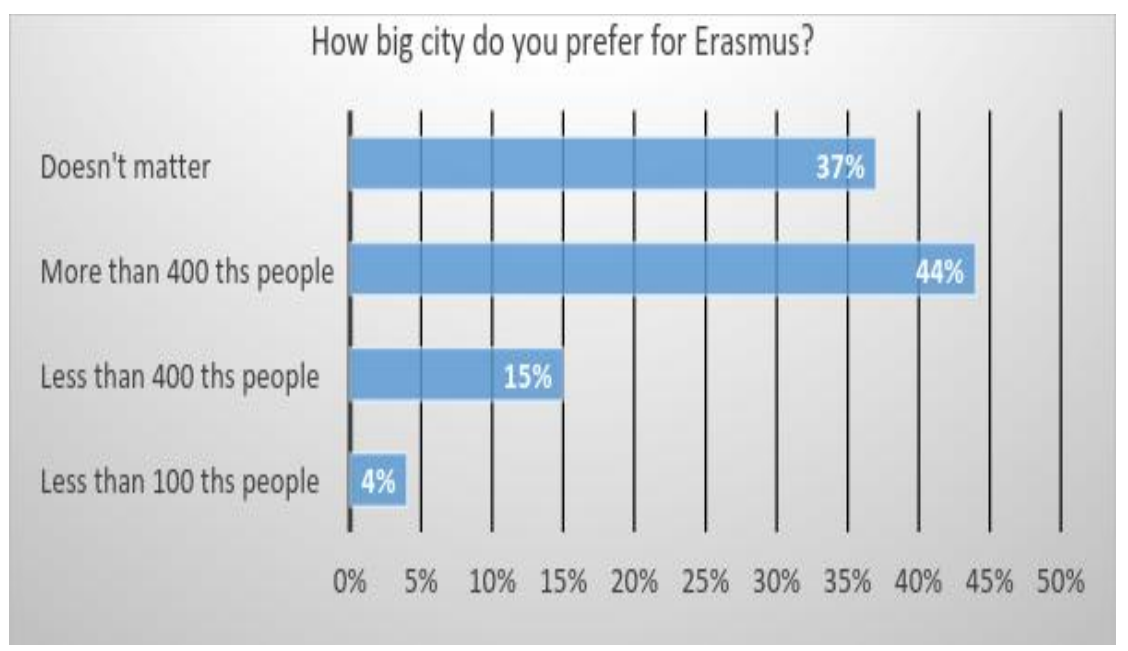

Fig. 12. How big city do you prefer for Erasmus mobility?

Source: own study.

The next question was about the distance from place of residence to go abroad to study. Majority of students replies shown that it didn't matter (43\%). The last two questions in the survey were to verify specific selection of the city to which students would like to come on of Erasmus during their studies (Fig.13). One of the questions concerned the city in the Czech Republic and one in Poland. The most popular city in the Czech Republic turned out to Prague with a large majority (91\%) over other cities of Brno which was the result of $7 \%$ and Ostrava with a score of $2 \%$. In Poland, the results proved to be more aligned. Most votes won the Polish capital - Warsaw (54\%) and closely followed by Cracow $35 \%$. For the last two places was Gdańsk - 7\% and Wroclaw - 4\%. All these cities are very attractive for tourists. 

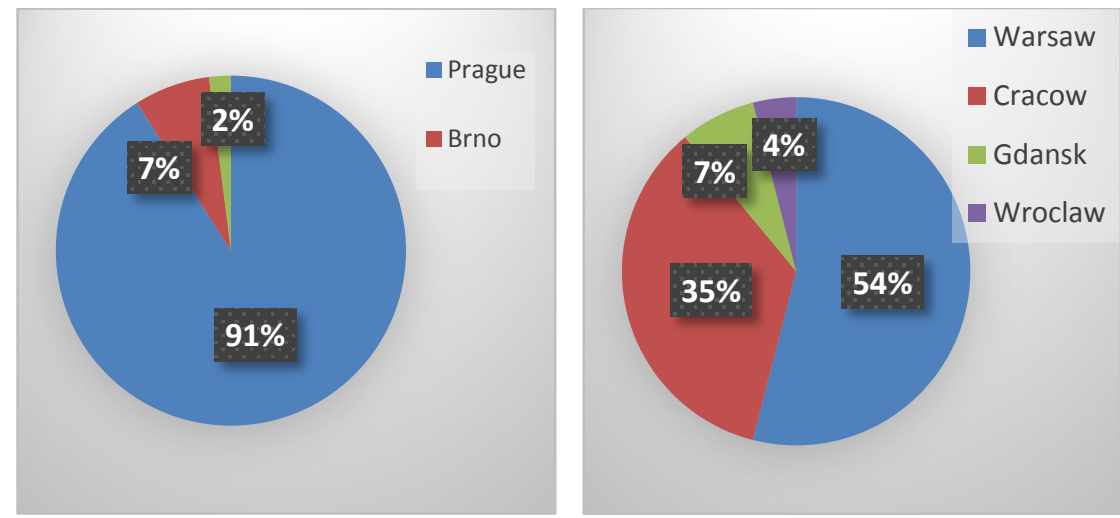

Fig. 13. Which city would you choose for Erasmus destination in:

a) Czech Republic, b) Poland.

Source: own study.

\section{Conclusion}

Year by year, the number of outgoing students under the Erasmus program grows. More and more money is spent on grants for students and employees. These are favorable conditions for the university to attract new students. Universities are expanding their educational offer by new courses in new languages. There are also offered various forms of teaching.

The number of bilateral agreements between teaching institutions is being increased. Universities are involved in new projects, internships and apprenticeships for students. There are new language projects aimed at improving the knowledge of the language of students. Thanks to that trips abroad for studies are becoming more desired, there are more and more willing students. With the introduction of new rules in the Erasmus + students were given the opportunity for trips abroad for several times: to study or practice.

As the survey showed, the choice of the place of departure of students is influenced by many factors. An important factor is the offer of the university but also the attractiveness of the region in which the school is 
located. Most are large cities both in Poland and the Czech Republic. Smaller universities should strongly promote their good points to encourage more students to come. The offer is so large that in the future, each student at least once should take part in the exchange program Erasmus.

Improvement of the university education offer within Erasmus+ programme need to identify catalogue of reasons for choosing the university as a Erasmus study destination. Authors identified in the paper some reasons such as: universities with long-standing reputations, unique conception and interesting specializations, affordable tuition fees and living costs, and last but not least, a vibrant and colourful cultural life in the heart of Europe. Erasmus+ enables students to study or train in a company abroad, as well as providing higher education staff with a chance to train or teach abroad. Skills and competences that cab ne gained during the Erasmus+ practice or knowledge resulting from acreditated programmes are profitable reasons that justify choice of the university as the Erasmus mobility destination.

There are some other reasons, like: location of the university, conditions of living or environment of the study related to the infrastructure. Mentioned arguments can create the higher quality of the Erasmus+ offer aimed at increase of SMS and SMP mobilities.

The Erasmus+ mobility increase of the incoming and outgoing students numbers requires not only improvement of the education offer and conditions of living but also appropriate administrative services for host and home students what is connected with the coordinators work quality and administrative procedures elaboration.

\section{Acknowledgements}

This work is related to the scientific research programme connected with the objectives of the Students Scientific Group Erasmus+Manager activity at Faculty of Management, Czestochowa University of Technology founded on 19 April 2016 by decision of the Scientific Board of the Faculty of Management. The paper was prepared by outgoing student BSc Olga Śpiewak who participated in Erasmus+ mobility twice: at University of Ljubljana in Slovenia (2013) and at Czech Life Sciences University in Czech Republic (2016). 


\section{Bibliography}

1. http://esn.org/history

2. http://www.bbc.co.uk/history/historic_figures/erasmus.shtml

3. http://www.erasmus.org.pl/odnosnikipodstawowe/statystyki\#Mobilnosc_w_ramach_Erasmusa_w_Polsce__dane_w_podziale_na_uczelnie

4. Narodowa Agencja Programu Erasmus+, Warszawa 2015, Erasmus w Polsce w roku akademickim 2013/2014, ISBN: 978-83-64032-82-0

5. http://ec.europa.eu/education/library/statistics/erasmus-plusstatistics/index.html

6. Erasmus - Facts, Figures \& Trends. The European Union support for student and staff exchanges and university cooperation in 2013-14 Luxembourg: Publications Office of the European Union

7. http://ec.europa.eu/education/library/statistics/ar-statistical-annex_en.pdf

8. http://ec.europa.eu/education/study-in-europe/country-profiles/czechrepublic_en.htm

9. http://www.naep.cz/index.php?a=view-projectfolder\&project_folder_id $=301 \&$

10. http://ec.europa.eu/education/library/statistics/2014/czech-republic_en.pdf

11. http://www.cuni.cz/UKEN-145.html

12. http://www.cuni.cz/UKEN-142.html

13. http://www.topuniversities.com/universities/charles-universityprague/undergrad

14. http://en.uw.edu.pl/pl-one-of-the-most-popular-erasmus-destination/

15. http://www.thecompleteuniversityguide.co.uk/international/europe/poland/

16. http://www.studyinpoland.pl/en/

17. http://www.erasmus.org.pl/odnosniki-podstawowe/statystyki

18. http://www.pcz.pl/english/

19. http://www.pcz.pl/english/studies-in-english

20. http://www.erasmus.org.pl/odnosnikipodstawowe/statystyki\#Mobilnosc_w_ramach_Erasmusa_w_Polsce__dane_w_podziale_na_uczelnie 